\title{
Challenges in Managing Waste from Extractive Industries during the Transition to a Circular Economy Model in Poland ${ }^{\dagger}$
}

\author{
Joanna Kulczycka * (D) and Ewa Dziobek (D)
}

Mineral and Energy Economy Research Institute Polish Academy of Sciences, Wybickiego 7A Str.,

31-261 Cracow, Poland; ewadziobek@meeri.pl

* Correspondence: kulczycka@meeri.pl; Tel.: +48-605-333-363

+ Presented at International Conference on Raw Materials and Circular Economy, Athens, Greece, 5-9 September 2021.

\section{check for}

updates

Citation: Kulczycka, J.; Dziobek, E. Challenges in Managing Waste from Extractive Industries during the Transition to a Circular Economy Model in Poland. Mater. Proc. 2021, 5, 42. https://doi.org/10.3390/ materproc2021005042

Academic Editor: Anthimos Xenidis

Published: 30 November 2021

Publisher's Note: MDPI stays neutral with regard to jurisdictional claims in published maps and institutional affiliations.

Copyright: (c) 2021 by the authors. Licensee MDPI, Basel, Switzerland. This article is an open access article distributed under the terms and conditions of the Creative Commons Attribution (CC BY) license (https:// creativecommons.org/licenses/by/ $4.0 /)$.

\begin{abstract}
Proper waste management is an essential part of the efficient use of natural resources and sustainable economic growth. One of the largest waste streams in the European Union and in Poland is waste from extractive industries. Appropriate treatment of this waste stream should therefore be a priority, based on the applicable waste hierarchy. The use of the waste management hierarchy was confirmed by the analyzed data. Despite the growing demand for mineral resources, the amount of generated extractive waste is decreasing and waste recovery is increasing. The paper presents the main challenges in the management of waste from the mining industry in Poland, taking into account not only the existing regulations but also future actions resulting from the Polish Road Map toward the transition to a circular economy.
\end{abstract}

Keywords: waste management; waste hierarchy; extractive industry; circular economy

\section{Introduction}

Conducting proper waste management is crucial for the efficient use of natural resources and sustainable economic growth. The first priority is to focus on the sectors that account for the largest share of waste generation. Both in Poland and in the entire EU, mining and quarrying is such a sector, generating almost $27 \%$ and $37 \%$ of all waste from all types of activities defined and presented in the statistical classification of economic activities in the European Community (NACE) and households (calculated on the basis of Eurostat, 2018) [1]. The importance of managing this group of waste has been emphasized in recent years by the introduction of the circular economy (CE) concept related to the increased demand for metals and other critical raw materials.

In December 2015, the EC announced "Closing the loop-An EU action plan for the Circular Economy" [2] with the proposed actions contributing to the transformation of the economic model of the Member States to the circular economy model. It resulted in the implementation of CE strategies by European cities, regions and countries. In Poland, in mid-June 2016, the Ministry of Development established the Interdepartmental Circular Economy Group in order to develop guidelines and indicate specific actions to be taken. In September 2019, the Road Map [3] was approved by the Polish Government, which defines the legal framework for implementing the $\mathrm{CE}$ for the coming years, as the first $\mathrm{CE}$ strategy in Central and Eastern Europe. The Road Map identifies the actions needed to increase resource efficiency and reduce waste and provides comprehensive tools for moving from a linear to a circular economy at each stage of the lifecycle. It focuses on five priority areas: (1) sustainable industrial production, (2) sustainable consumption, (3) bioeconomy, (4) new business models and (5) implementation, monitoring and financing of CE.

Successful implementation of the CE will depend primarily on the awareness, imagination and openness to the civilization challenges of the future. It is also important to monitor the transformation. 


\section{Materials and Methods}

First, a search was carried out using online research technique of reviewing European and national institutions to identify CE strategies [4]. This resulted in the selection of road maps and actions defined for the transition to the CE model and the identification of key sectors for the transition. The next part of the research was the development of indicators for the Polish transformation toward CE as a main part of the oto-GOZ project implemented at the government level [5]. Initial indicators were selected by the project partners based on the web search, literature review, EU projects and platform outcomes and $10 \mathrm{EU} C \mathrm{CE}$ key indicators [6]. Moreover, national indicators developed by some Member States were analyzed. The accuracy of developed Polish indicators was then assessed by companies representing selected sectors, including mining and quarrying. The vast majority of companies from mining sector assessed all indicators related to waste management as one of the most important. Therefore, the next step was to analyze statistical data from different sources to determine the share of mining and quarrying waste in total waste generated in Poland. As this sector generates a large proportion of total waste, the monitoring of the transition toward the $\mathrm{CE}$ should take into account the management of waste arising from exploration, extraction, physical and chemical processing of ores and other minerals in line with the waste management hierarchy. The last part of the research was related to the identification of waste generation and management of waste from various raw materials. Data analysis was based on regulations and publications as well as reports and data published by companies and submitted to regional authorities.

\section{Indicators for the Transformation toward Circular Economy in Poland}

The initial indicators were developed under the oto-GOZ project at the level of country, region and enterprise in order to use them in practice in shaping national and regional development policies. Indicators were defined separately for sustainable production and consumption-divided into main, supported and contextual, as well as existing and requested. During the process of developing CE indicators for sustainable production and consumption, one of the identified challenges was the selection of priority sectors for transformation toward CE in Poland. Based on the analysis of material and energy consumption as well as the amount of generated waste, five sectors were selected: construction; energy sector; chemical industry; agro-food industry; and mining and quarrying.

In the next stage, a survey was conducted among companies from selected sectors, the purpose of which was to examine the accuracy of the developed indicators, thanks to which it would be possible to assess the development of CE in Poland:

1. Materials and energy:

- Consumption of primary raw materials/revenues;

- Consumption of secondary raw materials/revenues;

- Consumption of critical raw materials/revenues;

- Renewable energy/total energy consumption;

- Consumption of water/revenues.

2. Waste according to waste hierarchy:

- Amount of waste generated;

- Amount of hazardous waste generated;

- Amount of waste reused;

- Amount of waste recycled;

- Amount of waste that has undergone other recovery processes;

- Amount of waste subjected to disposal;

- Amount of by-products produced.

3. Environment:

- $\mathrm{CO}_{2}$ emissions;

- Carbon footprint;

- LCA environmental footprint. 
4. Costs:

- Material and energy costs/total costs;

- Investments in CE projects;

- Fees for economic use of the environment/total costs.

5. Competitiveness and innovation:

- Number of certificates held, e.g., EMAS, environmental declarations;

- Number of CE patents obtained;

- Number of industrial symbiosis transactions for waste utilization/management;

- CE strategies developed;

- Number of investment orders adjusted to CE;

- Number of people trained in CE.

As over $80 \%$ of companies in the mining sector rated all indicators related to waste management as the most important, along with the share of renewable energy in total energy consumption, the research continued in the area of waste management.

\section{Generation of Waste from Economic Activities and Its Management, Case of Extractive Waste in Poland}

\subsection{Waste Generation}

Extractive waste is defined by the EU as waste resulting from the prospecting, extraction, treatment and storage of mineral resources and the working of quarries. In 2018, the mining and quarrying section in the EU (27) generated approx. $27 \%$ and in Poland approx. $37 \%$ of all waste from all types of activities defined and presented in the statistical classification of economic activities in the European Community (NACE) and households (calculated on the basis of Eurostat) [1].

As the extractive sector generates a large proportion of total waste, the monitoring of the $\mathrm{CE}$ transformation process should be in line with the waste management hierarchy. Proper management of extractive waste requires evaluation of the characteristics of waste by strategic environmental assessment and adequate monitoring [7].

\subsection{Waste Management}

The European and Polish waste policy is based on the applicable waste hierarchy: the waste framework directive- the Polish Act on Waste [8]. Lèbre and Corder (2015) adapted the waste management hierarchy to mining (Figure 1) [9].

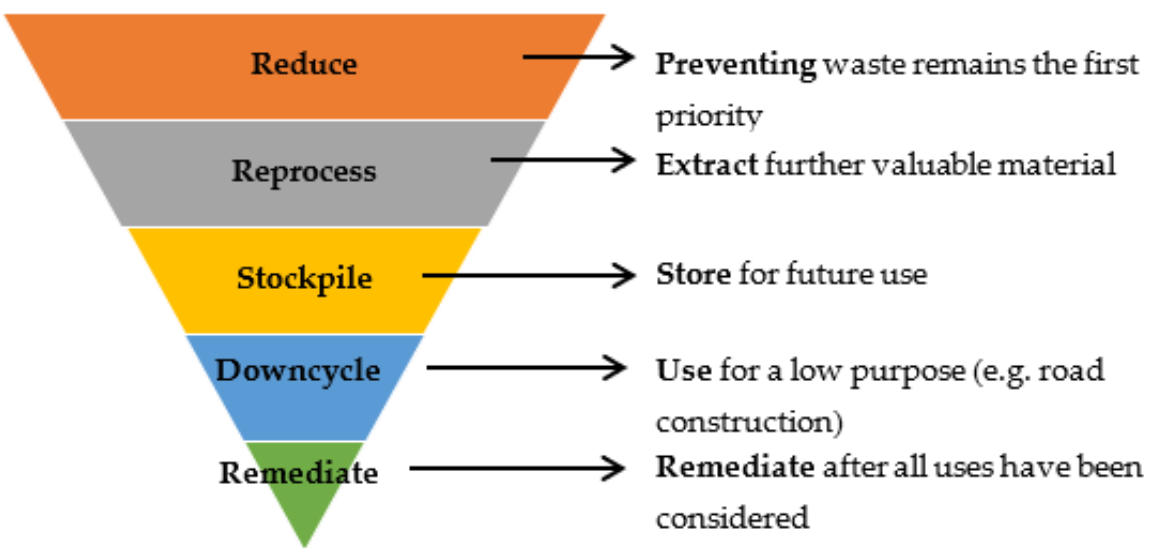

Figure 1. New hierarchy for mine waste management based on Lèbre and Corder (2015).

The application of the assumptions of the waste management hierarchy in the Polish mining industry led to a reduction in waste generation despite the growing demand for mineral resources and an increase in waste recovery. The analysis of data provided by the Central Statistical Office [10] confirmed that, despite the growing demand for mineral resources, mining and quarrying waste generated in Poland in 2019 at the level 
of 63.7 million tons was $9 \%$ lower than in 2015, whereas waste recovery has increased by more than $40 \%$, reaching 25.6 million tons, enabling an increasingly useful use of waste by replacing other materials and/or preparing waste to perform this function in the future.

\subsection{Management of Waste from Various Minerals}

Different types, quantities and properties of waste are generated at the extraction sites, depending on the raw material extracted, the process technology used and the local geology. In all analyzed reports and databases, the waste codes do not allow the identification of waste for individual raw materials and even of the group (energy, metal, industrial) of waste from the mining industry.

\subsubsection{Energy - Case of Lignite and Hard Coal}

In the case of lignite, there are various options for waste management and classification, but almost no extractive waste was recorded during lignite mining in Poland, and only from the largest mine, the owner reported small amounts of waste code 010412 to the regional office coming from the aggregate production plant (accompanying minerals outside the mining area) (Table 1).

Table 1. PGE Górnictwo i Energetyka Konwencjonalna S.A., Bełchatów-extraction of lignite and reported waste, ths. tons, 2017.

\begin{tabular}{cc}
\hline Extraction of lignite [11] & 63,060 \\
\hline Extractive waste ^ ${ }^{\wedge}$ generation & 19 \\
\hline Extractive waste $^{\wedge}$ recovery & 21 \\
\hline
\end{tabular}

Extractive waste compliant with EWC (European Waste Catalogue) waste code 010412 (washing and cleaning of minerals other than those mentioned in 010407 and 0104 11).

The reasons for the lack of waste from the lignite mining are as follows:

- The overburden is not classified as waste if it is stored in the mining area and is managed in accordance with the Geological and Mining Law [12];

- The intergrowth/interlayer in deposit is treated as overburden;

- Soil and rock mass moved within excavation is not classified as waste from the extractive industry if a proper document (concession or local plan for mining area or mining plan) defined conditions for its management;

- Associated minerals (by-products) sold or intended for sale in the future, such as gravel and sand, are not classified as waste.

In the case of hard coal, the extraction of one ton of coal is accompanied by $0.25-0.35$ tons of waste (in the $1980 \mathrm{~s}-0.5$ tons), and about $93 \%$ of waste produced during exploitation and processing of coal is used-out of which $30 \%$ is used industrially and $70 \%$ is applied to ground leveling and other engineering work. There are two main groups of wastes from hard coal mining and processing:

1. Mining wastes - up to $20 \%$ of the total, coming directly from preparatory mining works;

2. Processing wastes-depending on the type of processing equipment and technologies, divided into three subgroups: coarse-grained from dense medium gravity separation, fine-grained from jiggers and very fine-grained flotation wastes.

The basic way of managing waste is to deposit it on a dump close to the mine or a central one. A significant part is used to fill natural or anthropogenic depressions and used to be treated as land reclamation. Some of it is used as aggregates and material for the construction and building industry. In 2017, six hard coal mining companies reported to regional offices 25,243 ths. tons of waste from mineral excavation (01 01 02, 0104 12, 0104 07 and 0104 11, 0104 81) out of which 2034 ths. tons was recovered in installations and devices in 2017, 6789 ths. tons was recovered out of installations and devices and 7047 ths. 
tons was disposed of in installations and equipment. The total excavation production amounted to 56,824 ths. tons [11].

\subsubsection{Metal-Case of $\mathrm{Zn}-\mathrm{Pb}$}

ZGH "Bolesław" S.A. conducted zinc and lead ore mining in the Olkusz Pomorzany mine. Excavated output was transported to the mechanical processing, where, with the flotation process, concentrates of $\mathrm{Zn}$ and $\mathrm{Pb}$ are obtained and directed to smelters, where metallic $\mathrm{Zn}$ and $\mathrm{Zn}$ alloys are obtained. Generated waste is transported to the tailing ponds-a waste facility. Waste generation and disposal are presented in Table 2 (Małopolskie voivodship report on extractive waste).

Table 2. ZGH "Bolesław" S.A.—extraction of zinc and lead ore and reported waste, ths. tons, 2017.

\begin{tabular}{cc}
\hline Extraction of zinc and lead ore [11] & 1700 \\
\hline Extractive waste ^ generation $^{*}$ & 81 \\
\hline Recycling/reclamation of other inorganic material recovery ${ }^{\wedge}$ & 81 \\
\hline Extractive waste $^{\wedge}$ generation ${ }^{*}$ & 1801 \\
\hline Recycling/reclamation of other inorganic material recovery ${ }^{\wedge}$ & 1787
\end{tabular}

* Also from secondary sources. ^ Extractive waste compliant with EWC waste code 010180 (rock waste from copper, zinc and lead mining). ^ Extractive waste compliant with EWC waste code 010381 (wastes from the flotation enrichment of non-ferrous ore wastes).

Nowadays (from 2020), ZGH “Bolesław" S.A. reuse waste and produce zinc and lead from their own tailings dam.

\subsubsection{Waste Management in Poland-Case of Dolomite}

PPH "Dolomit" Sp. z o.o. in Libiąż produce stone building elements, aggregates and calcium-magnesium carbonate fertilizer. Only a small amount of waste is reported. Waste generation and disposal in 2017 are presented in Table 3.

Table 3. PTC "Dolomit"—extraction of dolomite and reported waste, ths. tons, 2017.

\begin{tabular}{|c|c|}
\hline Extraction of dolomite (Libiąż deposit) [11] & 580 \\
\hline Extractive waste ${ }^{\wedge}$ generation & 5 \\
\hline Deposit into or onto land, e.g., landfill`^ & 0.7 \\
\hline Extractive waste ${ }^{\wedge}$ generation & 0.1 \\
\hline Deposit into or onto land, e.g., landfill ^ & 0.1 \\
\hline
\end{tabular}

\section{Conclusions}

The transition to the CE model in Poland requires monitoring. The primary selection of indicators was made under the oto-GOZ project. Based on the analysis of material and energy consumption and the amount of generated waste, five sectors essential for transformation toward $\mathrm{CE}$, including mining and quarrying, were identified and involved in the assessment of the accuracy of environmental, social and economic indicators. Over $80 \%$ of companies from the mining sector, which produces the largest part of waste in Poland, rated all indicators related to waste management as the most important. Therefore, proper management of extractive waste should be a priority and should be based on a waste management hierarchy adapted to the mining industry. The application of the hierarchy leads to a reduction in waste generation and an increase in waste recovery.

Although reporting of extractive waste is limited due to different types, amounts and properties of waste generated at extraction sites during the extraction of various raw 
materials, the process technology used and the local geology, as well as the inability to identify individual groups (energy, metal, industrial) of extractive waste based on the waste codes, certain conclusions can be drawn based on the analysis carried out:

1. Almost no waste from the extractive industry during lignite mining in Poland is reported;

2. Extraction of one ton of coal is accompanied by $0.25-0.35$ tons of waste generated;

3. Some open-pit industrial mineral producers do not report extractive waste-minerals are processed within excavation and, in that case, only contaminated soil and rock mass could be reported as waste.

Author Contributions: Conceptualization, J.K. and E.D.; methodology, J.K. and E.D.; formal analysis, J.K. and E.D.; investigation, E.D.; resources, E.D.; data curation, J.K. and E.D.; writing—original draft preparation, E.D.; writing—-review and editing, J.K.; visualization, E.D. All authors have read and agreed to the published version of the manuscript.

Funding: The project is co-funded by the National Center for Research and Development as part of the first competition for projects open under the Strategic Program of Scientific Research and Development "Social and economic development of Poland in the conditions of globalizing markets"-GOSPOSTRATEG, agreement. Gospostrateg1/387784/24/NCBR/2019.

Institutional Review Board Statement: Not applicable.

Informed Consent Statement: Not applicable.

Data Availability Statement: Most of the data presented in this study are openly available in Eurostat databases and study of the Polish Geological Institute (details are given in references). The data on waste generated by individual companies are partially openly available and partially obtained from Polish regions (Provincial Offices).

Conflicts of Interest: The authors declare no conflict of interest.

\section{References and Notes}

1. Eurostat Database. Available online: https://ec.europa.eu/eurostat/statistics-explained/index.php?title=File:Waste_generation_ by_economic_activities_and_households,_2018_(\%25_share_of_total_waste_)_30-04-2021.png (accessed on 23 July 2021).

2. EC (2015) Communication from the Commission to the European Parliament, the Council, the European Economic and Social Committee and the Committee of the Regions: Closing the Loop-An EU Action Plan for the Circular Economy; COM (2015) 0614 Final; European Commission: Brussels, Belgium, 2015.

3. The Roadmap of Transformation towards Circular Economy. Available online: https://www.gov.pl/web/przedsiebiorczosctechnologia/rada-ministrow-przyjela-projekt-mapy-drogowej-goz (accessed on 26 July 2021).

4. Nowaczek, A.; Kulczycka, J.; Pẹdziwiatr, E. Przegląd Wskaźników Gospodarki o Obiegu Zamkniętym w Dokumentach Strategicznych Wybranych Krajów UE (Overview of Circular Economy Indicators in Strategic Documents of Selected EU Countries) in Gospodarka o Obiegu Zamkniętym w Polityce i Badaniach Naukowych (Circular Economy in Politics and Research); Kulczycka, J., Ed.; Instytut Gospodarki Surowcami Mineralnymi i Energią Polskiej Akademii Nauk: Kraków, Poland, 2019; ISBN 978-83-955544-5-2. e-ISBN 978-83-956380-0-8.

5. Oto-GOZ Project Webpage. Available online: https:// circularhotspot.pl/pl/oto-goz (accessed on 23 July 2021). (In Polish).

6. Eurostat. Available online: https://ec.europa.eu/eurostat/web/circular-economy/indicators (accessed on 23 July 2021).

7. Kulczycka, J.; Dziobek, E.; Szmiłyk, A. Challenges in the management of data on extractive waste-The Polish case. Miner. Econ. 2020, 33, 341-347. [CrossRef]

8. Ustawa z dnia 14 grudnia 2012 r. o odpadach (The Act of 14 December 2012 on waste), Dz.U.2021.779.

9. Lèbre, É.; Corder, G. Integrating Industrial Ecology Thinking into the Management of Mining Waste. Resources 2015, 4, 765-786. [CrossRef]

10. Environment (2016, 2020), GUS Mining and quarrying Section B Polish Classification of Activities (Sector 05-09) Central Statistical Office.

11. Bońda, R.; Brzeziński, D.; Czapigo-Czapla, M.; Czapowski, G.; Kalinowska, A.; Malon, A.; Mikulski, S.Z.; Miśkiewicz, W.; Oszczepalski, S.; Siekiera, D.; et al. Bilans Zasobów Złóż Kopalin w Polsce wg Stanu na 31 XII 2017 r. (Balance of Mineral Resources in Poland as at 31 December 2017). 2018. Available online: http://geoportal.pgi.gov.pl/css/surowce/images/2017 /pdf/bilans_2017.pdf (accessed on 26 July 2021).

12. Ustawa z dnia 9 czerwca 2011 r. Prawo geologiczne i górnicze (The Act of 9 June 2011 Geological and Mining Law), Dz.U.2011, Nr 163 poz. 981). 